Volume 1, Number 1, 2015

\title{
Drying of Antioxidant Composite Materials based on Table Beet
}

\author{
Zhanna Petrova $^{a}{ }^{*}$, Yuriy Snezhkin ${ }^{a}$, Vadym Pazyuk $^{b}$, Kateryna Samoilenko $^{a}$ \\ ${ }^{a}$ Institute of Technical Thermal Physics, National academy of sciences of Ukraine, Bulakhovskogo Str., 2, \\ Kyiv, 03164 Ukraine \\ ${ }^{b}$ Vinnytsia national agrarian university, Soniachna Str., 3, Vinnytsia, 21008 Ukraine
}

Received: May 12, 2015. Revised: June 02, 2015. Accepted: June 30, 2015.

(C) 2015 The Authors. Published by Lviv Polytechnic National University.

\begin{abstract}
Reduction in the cost of energy in the food industry is an important challenge today due to increased prices. Drying process of plant material refers to the complex energy-intensive processes. Solution of this problem is the development of drying methods that would reduce energy consumption by the process. In the drying of plant material, another major factor is the quality indicators of the finished product, which depend mainly on the drying technology. Therefore, in the Institute of Technical Thermal Physics, energy-efficient drying modes of plant material that made it possible to reduce energy consumption at the drying process and to preserve the biologically active substances of the feedstock were developed. Research is devoted to developing energy-efficient drying modes of antioxidant materials based on table beet that provide betanin saving by $95 \%$ and reducing energy consumption by $49 \%$. Today in Ukraine, there are not enough companies processing plant materials in powder, thus preserving the quality of the feedstock.
\end{abstract}

Keywords: antioxidants; beet; betanin; drying; saving; energy costs.

1. Definition of the problem to be solved. Considering the general trend of energy consumption, which leads to increased energy consumption in the world, the cost of energy is increasing continuously and its deficit is growing. Therefore, the issue of creating energy efficient drying modes that ensure the reduction of energy with maximum preservation of biologically active substances is quite pressing. This is especially topical for providing food to people because additional difficulty is that the production and processing of agricultural products results in high consumption of gas and other energy sources with low efficiency and large losses in the processing of plant materials.

2. Analysis of the recent publications and research on the problem. In Ukraine, scientific research on the conservation of coloring substances of plant material in the processing of berries, fruit and vegetables which have antioxidant properties has been recently renewed. These areas are studied by the scientists of Kharkiv State University of Food Technology and Trade, Odessa National Academy of Food Technologies, Poltava University of Consumer Cooperation of Ukraine and others [1-3].

During the beet juice solution heating, betanin and red-purple color decreases to the gradual accumulation of brown products. For example, heating beet juice solution for 30 minutes at $85{ }^{\circ} \mathrm{C}$ leads to betanin losses of up to $10 \%$, at $115{ }^{\circ} \mathrm{C}-80 \%$, at $120{ }^{\circ} \mathrm{C}-100 \%$. Table beet blanching and juice processing results in betanin losses of $20 \ldots 40 \%$ and $40 \ldots 50 \%$ respectively [4].

Based on the above we can conclude that betanin is a thermolabile pigment that is destroyed during blanching, sterilization and other types of processing.

3. The goal of the paper is the development of energy-efficient drying modes of antioxidant plant material based on the table beet with maximum preservation of betanin and reduction in energy consumption in the process.

4. Presentation and discussion of the research results. Vegetables and fruit processing, during prolonged storage, results in partial destruction of biologically active components and reduction in the functional value of the

\footnotetext{
* Corresponding author. Email address: bergelzhanna@ukr.net
} 
finished product [5-6]. Maximum preservation of biologically active substances in the finished product is an important challenge.

Plant combined compositions based on table beet are complex in structure, physico-chemical and biochemical composition. Beet is the only culture which contains betanin - enzymatic decay product of choline, which plays an important role in metabolism of human body. Preservation of the maximum levels of betanin is achieved through a combination of table beet with plant material that contains organic acids, stabilizing betanin, which is a natural antioxidant.

Antioxidants are natural or identical to natural, multifunctional substances involved in different levels of metabolism, synthesis and transformation of biologically active metabolites. They are themselves able to prevent oxidation of the active chemicals in the cells of the human body or provide the necessary activity of antioxidant systems of the body - universal control system which controls the level of free radical oxidation reactions and prevents the accumulation of toxic oxidation products [7].

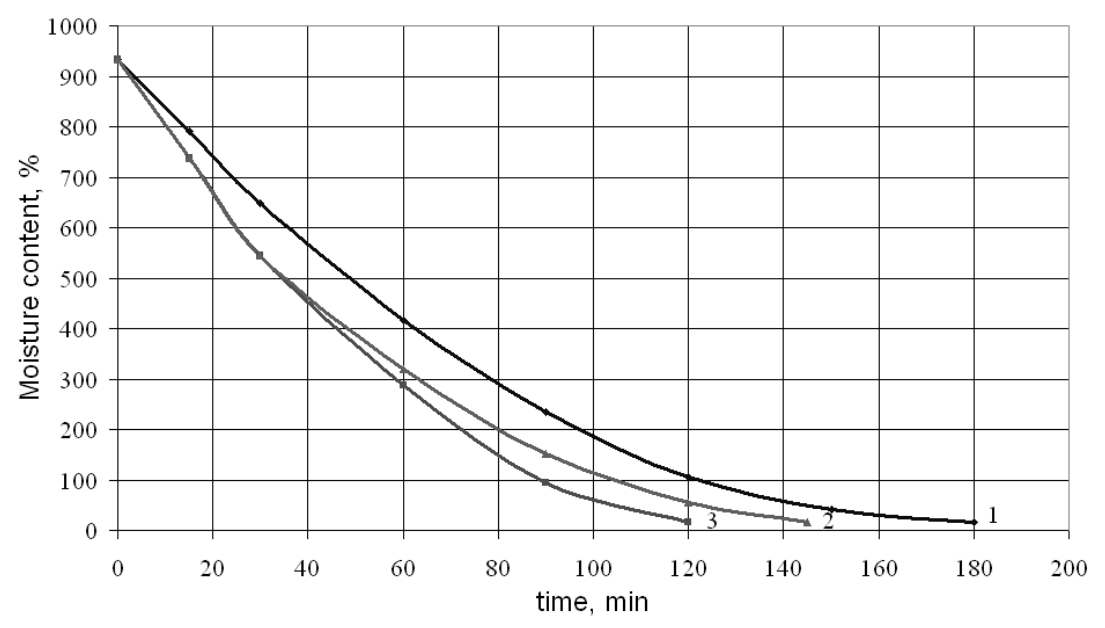

a

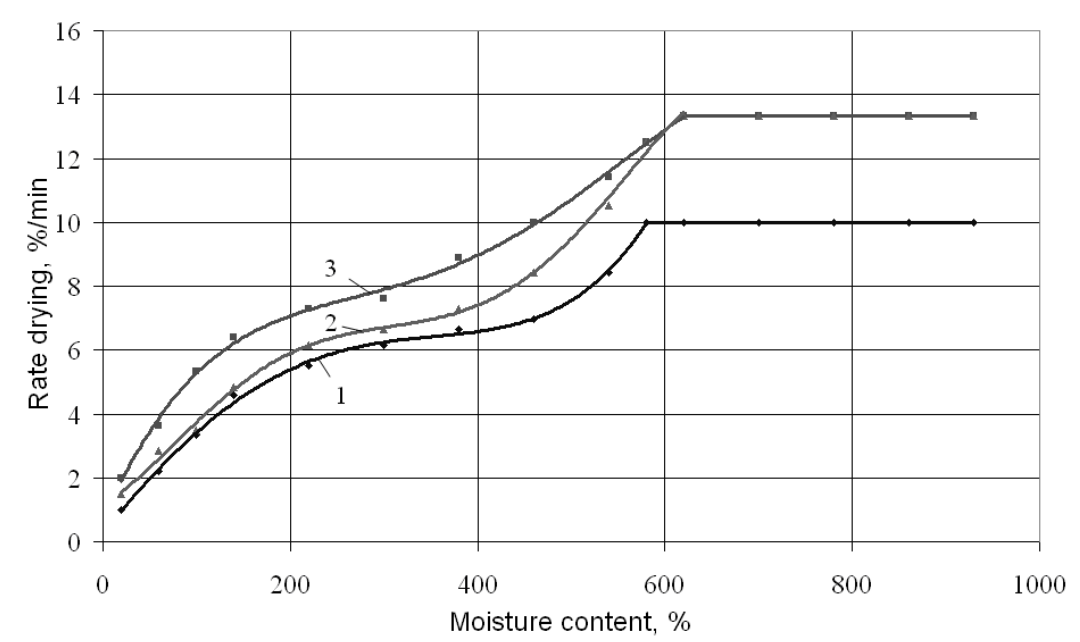

b

Fig. 1. Drying curves (a) and drying rate (B) of antioxidant materials based on table beet in the layer $\delta=10 \mathrm{~mm} ; \mathrm{V}=1,5 \mathrm{~m} / \mathrm{c} ; \mathrm{d}=10 \mathrm{~g} / \mathrm{kg}$ to drying modes: $1-60{ }^{\circ} \mathrm{C} ; 2-100 / 60{ }^{\circ} \mathrm{C} ; 3-100{ }^{\circ} \mathrm{C}$

Choice of the best drying method is always determined by the nature of the material and quality requirements of the final product. In most cases, the latter is the main factor, since obtaining the final product with desired characteristics (low moisture content, porosity, saving component of type substances, natural color stabilization, minimal loss of material during storage, etc.) can be efficiently implemented using only certain ways and dehydration modes.

Convective drying processes refer to the most energy-intensive industrial processes. Cost of energy to remove moisture reaches $3000-5000 \mathrm{~kJ} / \mathrm{kg}$ or more, therefore the issue of energy consumption reduction in drying is a relevant scientific and technical challenge. 
One solution to this problem is the development of the energy efficient drying modes. Stepped drying modes of functional material were developed; they were tested on the research - industrial unit at the Institute of Technical of Thermal Physics NAS of Ukraine [8].

Drying kinetics curves of antioxidant raw materials based on table beet, on industrial dryer, are shown in Fig. 1.

Increase in the heat carrier temperature from 60 to $100^{\circ} \mathrm{C}$ reduces the time of drying of antioxidant raw materials based on table beet by 1.5. Stepped drying mode is proposed to reduce the drying compared to drying mode at $60{ }^{\circ} \mathrm{C}$ by $24 \%$. Stepped drying mode lasts for $30 \mathrm{~min}$ at $100{ }^{\circ} \mathrm{C}$, then temperature decreases to $60^{\circ} \mathrm{C}$ and is maintained at this level until the end of the drying process.

The curves of drying rate of antioxidant materials based on table beet showed that there is constant drying rate period (Fig. 1) and the falling drying rate period. Curves character in a period of falling drying rate of the drying mode does not change.

Drying rate in the first period, the with the heat carrier temperature of $100{ }^{\circ} \mathrm{C}$, and stepped drying mode $100 / 60{ }^{\circ} \mathrm{C}$ coincide, then drying intensity in stepped mode decreases with temperature drop to $60^{\circ} \mathrm{C}$. The drying rate of the stepped mode as compared to $60{ }^{\circ} \mathrm{C}$ mode increases by 1.4 times.

Choice of the drying mode of antioxidant raw materials based on table beet was controlled based on betanin content change in the drying process (Fig. 2).

Fig. 2. Betanin preservation in the antioxidant raw material based on table beet depending to the drying mode

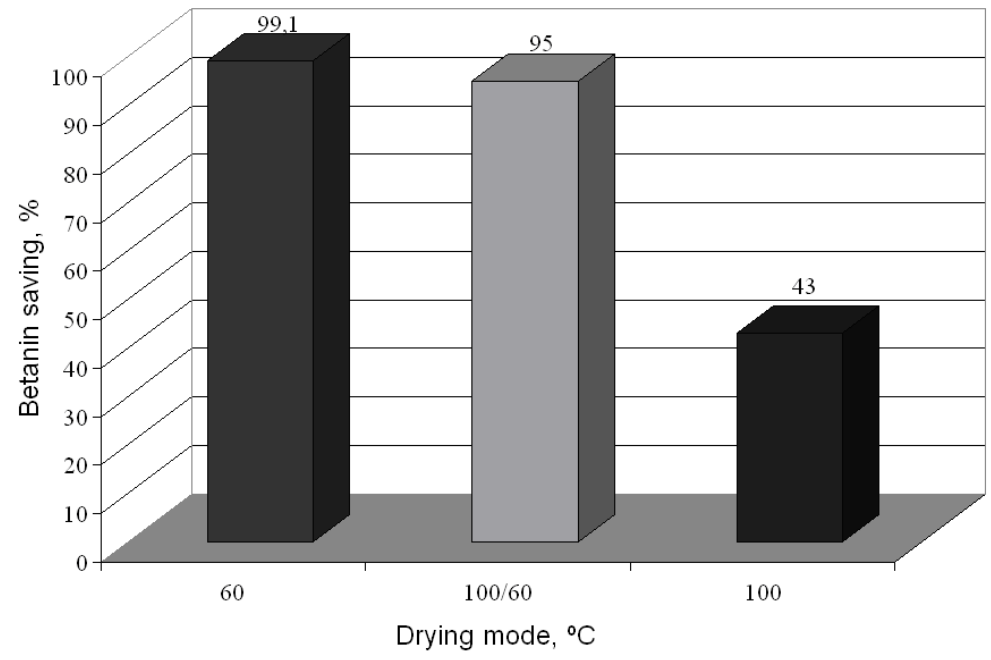

The best betanin preservation $\left(99.1 \%\right.$ ) is observed at heat carrier temperature of $60{ }^{\circ} \mathrm{C}$, stepped drying mode provides lover betanin preservation by $4.1 \%$. At $100^{\circ} \mathrm{C}$, nearly half of betanin is destroyed (43\%), while the color of beet-lemon mixture changes from red to brown, which indicates betanin destruction.

In the stepped mode $100 / 60^{\circ} \mathrm{C}$, relative specific heat consumption amounts to $51 \%$, which is less than that of the drying mode with heat carrier temperature of $60^{\circ} \mathrm{C}$ by $30 \%$ or less than that of the drying mode at $100^{\circ} \mathrm{C}$ by $49 \%$ (Fig. 3).

Fig. 3. The relative specific heat consumption depending on the drying mode of antioxidant raw materials based on table beet

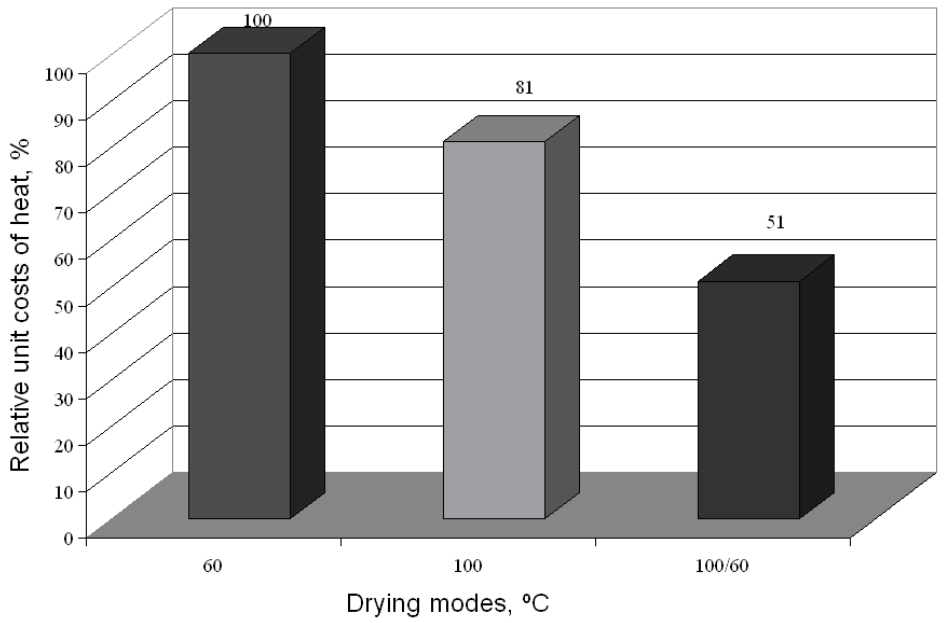


At the beginning, in the stepped drying mode, during constant drying rate period, the heat carrier temperature is maximum - due to intensive evaporation of moisture from the material, and the specific energy consumption is minimal. In the second period of drying, moisture evaporation decreases and heat carrier temperature is reduced.

On the basis of the conducted research, were designed energy-efficient drying modes which allowed reducing energy costs by $49 \%$ in comparison with the existing ones while saving betanin at $95 \%$.

\title{
5. Conclusions
}

1. Developed energy-efficient drying modes of antioxidant material based on table beet reduce energy consumption by $49 \%$.

2. Due to optimum drying modes, losses of biologically active substances are $1-5 \%$.

\section{References}

[1] Kaprelyants L. V. Functional Products / L. V. Kaprelyants, K. G. Iorgachova. - Odessa : Druk, 2003. - 312 p. (in Ukrainian)

[2] Raksha-Slyusareva O. A. Commodity and food additives ecohygiene / O. A. Raksha-Slyusareva // M. Tugan-Baranovskyi. - Donetsk: Donetsk National University of Economics and Trading. 2010. - 182 p. (in Ukrainian)

[3] Pavlyuk R. Y. New technologies of antotsyanic additives : monograph. / R. Y. Pavlyuk, V. V. Yanytskyy, T. V. Kryachko, G. I. Maksimenko, L. M. Sokolov, N. M. Maximov. - Kharkiv : National Institute of Food Technology and Trade - Kharkiv, 2008. - 261 p. (in Russian)

[4] Telezhenko L. N. Biological active substances for food / L. N. Telezhenko. - Odessa : Optimum. - 2004. - 268 p. (in Russian)

[5] Petrushevsky V. V. Biological active compounds for foodstuffs / V. V. Petrushevsky. - Kyiv : Urozhay, 1992. - 192 p. (in Russian)

[6] Bakulina O. N. Complex processing of fruits and vegetables in ingredients for modern food technology / O. N. Bakulina. // Food Industry. 2005. - No 5. - P. 32-34. (in Russian)

[7] Berry Ottaway P. The stability of Vitamins in Food. The Technology of Vitamins in Food / P. Berry Ottaway. - Glasgow : Blackie Academic and Professional Press. - 1993. - Ch. 5.

[8] Yu. Snezhkin. Determination of energy consumption when drying colloid capillary-porous materials / Yu. F. Snezhkin, N. A. Dabizha, R. A. Shapar // Industrial Heat Engineering. - 2003. - Vol. 25. - No. 4. - P. 198-200. (in Russian)

\section{Сушіння антиоксидантної композиційної сировини на основі столового буряку}

\author{
Жанна Петрова ${ }^{a}$, Юрій Снєжкін ${ }^{a}$, Вадим Пазюк $^{b}$, Катерина Самойленко $^{a}$ \\ ${ }^{a}$ Інститут технічної теплофізики НАН Украӥни, вул. Булаховського, 2, м. Київ, 03164 Україна \\ ${ }^{b}$ Вінницький національний аграрний університет, вул. Сонячна, 3, м. Вінниця, 21008 Украӥна
}

\section{Анотація}

Зниження затрат енергоносіїв у харчовій промисловості є актуальним завданням сьогодення у зв'язку 3 підвищенням цін на них. Процес сушіння рослинної сировини належить до складних енергоємних процесів. Одним із шляхів вирішення цієї проблеми є розробка таких способів сушіння, які б дали змогу знизити енергозатрати на процес. Під час сушіння рослинної сировини ще одним важливим фактором є якісні показники готового продукту, які залежать головно від технології сушіння. Тому в Інституті технічної теплофізики розроблено енергоефективні режими сушіння рослинної сировини, що дали можливість зменшити енерговитрати на процес сушіння та максимально зберегти біологічно активні речовини вихідної сировини. Досліджено розроблення енергоефективних режимів сушіння антиоксидантної сировини на основі буряку, які забезпечують збереження бетаніну на 95 \% і зменшення витрат енергії на 49 \%. Сьогодні в Україні недостатньо виробництва з переробки рослинної сировини в порошки, що дає змогу зберегти якість вихідної сировини.

Ключові слова: антиоксиданти; буряк; бетанін; сушіння; збереження; витрати енергії. 